\title{
O império da lei: ensaio sobre o cerimonial de sagração de D. Pedro I (1822)*
}

\section{Eduardo Romero de Oliveira**}

Este texto concentra-se no exame de um cerimonial régio da monarquia constitucional brasileira: a sagração e a coroação do Imperador D. Pedro I. Nosso exame deste cerimonial parte justamente do seu caráter litúrgico, para compreender por que este aspecto foi considerado essencial então para afirmar a autonomia do novo reino e, ao mesmo tempo, contribuiu para definir o poder político do Império do Brasil.

Palavras-chave: Cerimoniais Régios - Poder Monárquico - Teologia Política

The empire of law: an essay on the sacred ceremonial and royal coronation of Emperor D. Pedro I (1822)

The present article examines the royal ceremonies of the Brazilian constitutional monarchy, most particularly the sacred ceremonial and royal coronation of Emperor D. Pedro I. We have chosen to investigate this ceremony because its religious aspects, seeking to comprehend why religion played such a central role in supporting the authority of the new king and defining political power in Brazilian Empire.

Keywords: Royal Ceremonies - Monarchical Power - Theological Politics

l'empire de la loi: essai sur le cérémonial du sacre de D. Pedro I (1822)

Ce texte analyse le cérémonial royal de la monarchie constitutionnelle brésilienne: le sacre et le couronnement de l'Empereur D. Pedro I. Notre examen de ce cérémonial a comme point de départ son caractère liturgique, pour comprendre pourquoi cet aspect

\footnotetext{
"Artigo recebido em setembro de 2007 e aprovado para publicação em novembro de 2007.

*** Professor do Departamento de História da UNESP. E-mail: eduardo@rosana.unesp.br.
} 
a été considéré essentiel alors pour affirmer l'autonomie du nouveau royaume et, en même temps, a contribué pour définir le pouvoir politique de l'Empire du Brésil. Mots clés: Cérémonials Royaux - Pouvoir Monarchique - Théologie Politique

O texto concentra-se no exame de um cerimonial régio da monarquia constitucional brasileira - a sagração e a coroação do Imperador D. Pedro I - e o analisamos em vista de tentar determinar os elementos definidores da política no Império. ${ }^{1}$ Trata-se de um cerimonial de afirmação da autonomia política do Brasil, perante Portugal, que traz elementos definidores do poder político atribuído à D. Pedro porque procura fazer frente tanto às cortes portuguesas quanto às demais forças políticas nas províncias. Caracterização de um reino que se afirma autônomo, definição do poder real e confronto de forças são alguns dos tópicos presentes nesse cerimonial. Essa caracterização requer dois cuidados metodológicos: um primeiro trata de considerar o cerimonial em função dos procedimentos religiosos, dado que a monarquia portuguesa não os utilizava para este tipo de cerimonial; e, por segundo, será preciso analisar a função da religião para aqueles que compunham a comissão encarregada de organizar a sagração de D. Pedro I (entre eles, José Bonifácio de Andrada e Silva). ${ }^{2}$ Assim, nosso exame do cerimonial parte justamente do seu caráter litúrgico, para compreender por que este aspecto foi considerado essencial, então, para afirmar a autonomia e definir o poder político do novo Império.

\footnotetext{
${ }^{1}$ Já havia se admitido uma dimensão religiosa ao poder real, quando se projetou a aclamação de D. João V nos moldes de um cerimonial litúrgico de sagração, o qual não veio a ocorrer, sendo realizado o cerimonial de aclamação de D. João $\mathrm{V}$ conforme a forma admitida desde D. João IV. Então, além do poder real promover festas de devoção e prover igrejas de seu padroado, incluíra também a Capela Real como espaço privilegiado do cerimonial cortesão. Porém, o poder real procura afirmar-se a partir dos procedimentos religiosos. O projeto de sagração real propunha expandir a força do monarca através das instituições religiosas sob sua responsabilidade, mas o fazia dentro dos limites de um governo religioso. Em contrapartida, a imagem do sacrifício religioso seria capturada agora para redefinir o poder político quanto a seus objetivos e campo de atuação. Para detalhes e discussão em torno daquele projeto de sagração de D. João V, ver Ana Cristina Araújo, "Ritualidade e poder na corte de D. João V”, Revista de História das Idéias, Coimbra, v. 22, 2001, p. 179-201.

${ }^{2}$ A comissão era formada por José Bonifácio de Andrada e Silva, Frei Antonio de Arrábida (mestre do imperador), José Egydio Alvares de Almeida (Barão de Santo Amaro); José Caetano da Silva Coutinho (bispo do Rio de Janeiro) e Monsenhor Duarte Mendes de Sampaio Fidalgo (cônego da Sé do Rio de Janeiro e reitor do Seminário de N. S. da Lapa). Cf. Sacramento Blake, Dicionário Bibliográfico Brazileiro, Rio de Janeiro, Imprensa Nacional, 1892, v. II, p. 237, v. IV, p. 358-360.
} 


\section{Os estudos sobre a emancipação política do Brasil}

As condições atualmente possíveis para desenvolvermos nossa reflexão sobre o cerimonial e sua simbologia repousam numa certa configuração dos estudos históricos produzidos nas últimas três décadas. Uma linha de estudos, em particular, sistematizou os saberes políticos no Brasil oitocentista a partir da idéia de "princípios liberais". Trata-se de uma concepção antiga de que autores diversos (Locke, Montesquieu, Rousseau, Adam Smith e Benjamin Constant), tratados e conceitos (contrato, pacto social, vontade, povo e soberania) formam um sistema filosófico coerente (o "liberalismo") - do mesmo modo que, na história da filosofia, se tem referido a uma teoria do contrato. ${ }^{3}$ A esta concepção vinculou-se o pressuposto de que os fundamentos teóricos daqueles que lutaram no processo de independência política do Brasil foram retomados desses pensadores - como afirmam Cruz Costa e Maria Sylvia de Carvalho Franco. ${ }^{4}$

Dentro desta linha historiográfica, notamos variações de posturas sobre o caráter do liberalismo e os princípios atuantes no processo de independência política. Para alguns, como Maria Odila Dias, é menos um liberalismo político e mais um liberalismo econômico que deve ser privilegiado no estudo desses pensadores. Outros pesquisadores, como Emília Viotti da Costa, entendem que a formação deste ideário liberal foi um recurso ideológico, que deve ser entendido à luz da "transição do capitalismo comercial para o capitalismo industrial". ${ }^{5}$ No desdobramento destas várias demarcações, historiadores, como

\footnotetext{
${ }^{3}$ Este modo de conceber, aglutinando de Hobbes a Locke até Adam Smith para conceber o "Liberalismo moderno", é questionado por estudiosos como Pocock: "Isso me parece uma séria distorção da história, não porque Hobbes e Locke não tenham tomado parte em uma grande remodelagem da relação entre o direito e a soberania, desenvolvida no âmbito das premissas do paradigma [liberal] centrado na lei [isto é, o direito do indivíduo], mas porque estudar esse paradigma, e nada mais, leva a uma compreensão radicalmente equivocada dos papéis históricos desempenhados tanto pelo liberalismo quanto pela jurisprudência" (J.G. Pocock, As Linguagens do Ideário político, São Paulo, Edusp, 2003, p. 95). Reduzir a história do pensamento político nesses termos é escrevê-la apenas como história do liberalismo, entende Pocock. O que acaba por ignorar as distâncias epistemológicas, o debate teórico a que cada texto se dirige e os diferentes contextos históricos de cada autor.

${ }^{4}$ Cf. João Cruz Costa, "As idéias novas", in: Sérgio Buarque Holanda, O Brasil monárquico, São Paulo, Difel, 1965, Tomo II, v. 1, p. 179-190. Maria Sylvia de Carvalho Franco,”Organização social do trabalho no período colonial, in: Paulo Sérgio Pinheiro (org.), Trabalho escravo, economia e sociedade, Rio de Janeiro, Paz e Terra, 1984, p. 143-192.

${ }^{5}$ Cf. Maria Odila da S. Dias, "Aspectos da Ilustração no Brasil”, Revista do Instituto Histórico e Geográfico Brasileiro, Rio de Janeiro, v. 278, 1968. Cf. Emília V. da Costa, "Introdução ao estudo da emancipação política do Brasil", in: Carlos G. Mota (org.), Brasil em perspectiva, 3. ed., São Paulo, Perspectiva, 1971, p. 122-125. Fernando Novaes; Carlos Guilherme Mota, A independência politica do Brasil, 2. ed., São Paulo, HUCITEC, 1996, p. 70.
} 
Maria Lyra, que privilegiam, ao lado dos pensadores franceses, os princípios estabelecidos por Locke. ${ }^{6}$

A existência desse "sistema filosófico liberal" é um pressuposto de estudos sobre a cultura política do Império. Há análises dos inconfidentes mineiros e a composição das bibliotecas particulares que procuram provas materiais da influência escusa das "idéias liberais" nos movimentos insurrecionais. ${ }^{7} \mathrm{O}$ levantamento das bibliotecas particulares nas colônias do Brasil foi intensificado tanto por uma historiografia preocupada com os hábitos de leitura quanto para verificar a "contaminação" das bibliotecas por uma literatura ilustrada, mesmo aquelas não-subversivas. ${ }^{8}$ Mais recentemente, Lúcia Pereira das Neves tem estudado detalhadamente o comércio de livros. ${ }^{9}$ Por um lado, através do estudo da censura régia, destaca o consumo das "perigosas idéias francesas" e o vincula às insurreições. Por outro, devido a uma circulação mais intensa dos escritos e contatos com Portugal, sustenta a difusão de uma nova sensibilidade para reformas. Assim, as várias referências à liberdade, constituição nos impressos do período, talvez indicassem a existência de um campo conceitualmente homogêneo - dentro do qual estariam inseridas também as cerimônias régias. ${ }^{10}$ Os estudos sobre os periódicos políticos reconhecem estes princípios liberais, operando numa retórica ardilosa de um "estilo sedutor" que submeta

${ }^{6}$ Cf. Maria de Lourdes Vianna Lyra, A utopia do poderoso Império - Portugal e Brasil: bastidores da política, 1798-1822, Rio de Janeiro, Sette Letras, 1994. Ver especialmente o capítulo "O impacto das novas idéias: as vertentes da Ilustração", p. 28-31.

${ }^{7}$ Ver as notas críticas de Rodrigues Lapa, em Tomás Antonio Gonzaga, Tratado de Direito Natural, Rio de Janeiro, INL, 1957. Lapa foi também editor das Obras completas de Gonzaga. Eduardo Frieiro, O diabo na livraria do cônego, 2. ed., Belo Horizonte, Itatiaia/São Paulo, EdUSP, 1981.

${ }^{8}$ Luis Carlos Villalta, "O diabo na livraria dos inconfidentes", in: Antonio Novaes (org.), Tempo e História, São Paulo, Companhia das Letras, 1992, p. 367-395. Luis C. Villalta, "O que se fala e o que se lê: Língua, instrução e leitura", in: Laura de Mello Souza, História da Vida Privada no Brasil, São Paulo, Companhia das Letras, 1997, p. 331-385.

${ }^{9}$ Lucia Maria B. P. Neves, "Comércio de livros e censura de idéias: a actividade dos livreiros franceses no Brasil e a vigilância da Mesa do Desembargo do Paço (1795-1822)", Ler História, 23, p. 61-78, 1993. Lucia Maria B. P. Neves, "O privado e o público nas relações culturais do Brasil com Portugal e França (1808-1822)”, Ler História, 37, p. 95-111, 1999.

${ }^{10} \mathrm{O}$ estudo do vocabulário político teve no Brasil alguns trabalhos de destaque, como o de Lúcia Maria B. P. Neves, Corcundas, Constitucionais e Pés-de-Chumbo: a cultura política da Independência (1820-1822), Tese (Doutoramento em História), FFLCH-USP, São Paulo, 1992. No exterior, um trabalho conceituado sobre o problema da elaboração de um vocabulário político é o de R. J. Barman, Brazil: the forging of a Nation (1798-1850), Califórnia, Stanford University Press, 1988. Ou também o trabalho de Telmo Verdelho, num estudo sobre o movimento do Porto, em Portugal: Telmo Verdelho, As palavras e as idéias na Revolução Liberal de 1820, Coimbra, Inst. Nacional de Investigação Científica, 1981. 
o público leitor. ${ }^{11}$ Por sua vez, Iara Souza defende a tese de que um "pacto" foi celebrado entre o imperador e o povo. ${ }^{12}$ Enfim, procura-se reconstituir uma economia da circulação dos princípios liberais no mundo luso-brasileiro, que teria estimulado tanto a reforma do sistema político-administrativo quanto os movimentos insurrecionais.

Em contraste com esta linha devotada ao estudo dos "princípios liberais" da independência política, há outra que destaca o caráter multifacetado e não-uniforme do "Iluminismo europeu". Luiz Cabral de Moncada produziu um pequeno texto sobre Luis Antonio Verney ${ }^{13}$ no qual ressalta a existência de um Iluminismo de caráter particular nos países católicos (Itália, Espanha e Portugal) - um "Iluminismo cristão e católico" em que o triunfo da razão deu-se sobre os auspícios de um direito natural laico; que não era hostil ao cristianismo, mas sustentou um laicismo do poder real, emancipado da teologia. Enfim, segundo Moncada, esse Iluminismo cristão é que deu o tom reformista e humanista, ainda vivo como idéia política no fim do século XVIII.

Francisco Falcon observa que, na península ibérica, e mais ainda na escola conimbricense, opunha-se um "racionalismo jesuítico" a um "racionalismo moderno", ${ }^{14}$ do que deriva uma "defasagem" do movimento ilustrado hispanoportuguês em relação ao contexto geral da Europa. A análise do movimento ilustrado português supõe uma nova defasagem da sociedade lusa em relação à Espanha, segundo Falcon. Essa dupla defasagem e a governação pombalina viabilizaram um ideário mercantilista e ilustrado. Não apenas pelo rigor e exame detalhado de textos no período, este estudo é particularmente caro a nós porque aponta uma distância entre o movimento ilustrado na Europa e a de Ibérica. Falcon argumenta que houve numa "releitura" do discurso ilustrado, em função das condições existentes em Portugal no período pombalino.

Nesse sentido, destacamos alguns estudos de Guilherme Pereira das Neves sobre o Seminário de Olinda e mais particularmente do pensamento político de José Joaquim da Cunha Azeredo Coutinho. ${ }^{15}$ Neves mostra um

\footnotetext{
${ }^{11}$ Ver Cecília H. de Salles Oliveira, A astúcia liberal: relações de mercado e projetos políticos no Rio de Janeiro (1820-1824), Bragança Paulista, EDSF/ICONE, 1999.

${ }^{12}$ Cf. Iara Lis Souza, A pátria coroada, São Paulo, Unesp, 1999.

${ }^{13}$ Luis Cabral de Moncada, Um "iluminista” português do século XVIII: Luís Antonio Verney, São Paulo, Saraiva, 1941.

${ }^{14}$ Francisco J. C. Falcon, A época pombalina, São Paulo, Ática, 1982, p. 153-160.

${ }^{15}$ Guilherme P. das Neves, "Pálidas e oblíquas luzes: J.J. da C. de Azeredo Coutinho e a Análise sobre a justiça do comércio do regate dos escravos", in: Maria Beatriz N. da Silva (org.), Brasil: colonização e escravidão, Rio de Janeiro, Nova Fronteira, 2000, p. 349-370. G. P. Neves, "Do império luso-brasileiro ao império do Brasil (1789-1822)", Ler História, v. 27-28, p. 75-102, 1995. G. P. Neves, "Como um fio de Ariadne no intrincado labirinto do mundo: a idéia do império luso-brasileiro em Pernambuco (1800-1822)”, Ler História, v. 39, p. 35-58, 2000.
} 
Azeredo Coutinho que defende idéias de justiça da escravidão, verdade e natureza que estão distantes do pensamento ilustrado francês; déias vinculadas provavelmente a autores italianos e da Aufklärung alemã, do que deriva uma postura teleológica e de defesa do poder absoluto do monarca - no entendimento de Guilherme das Neves, pautando-se em Buarque de Holanda. ${ }^{16}$ Compreensível como um ilustrado, mas não dentro de um modelo único de Ilustração.

Novamente aqui, para explicar as aparentes contradições de um pensamento de fins dos Setecentos português, há que se considerar as particularidades do movimento ilustrado em Portugal, como destacaram acima Cabral de Moncada e Francisco José Falcon. Isso traz conseqüências para pensar os fundamentos teóricos das personagens envolvidas no processo de independência política do Brasil. Nosso exame sobre o cerimonial da sagração explora justamente as referências internas ao mundo luso-brasileiro, derivadas do pensamento português e de sua cultura política, matizando-as com referências externas (dos jusnaturalistas italianos ou alemães). Através dele, esperamos identificar os desvios e particularidades do saber político no Brasil oitocentista.

\section{O problema da origem dos procedimentos religiosos no cerimonial da sagração}

Propomos aquele primeiro cuidado metodológico com intenção de inquirir que possíveis modelos cerimoniais os organizadores poderiam ter em mãos para compor o da sagração de D. Pedro I. Já se observou, com propriedade, que os reis portugueses jamais tinham sido sagrados, mas tão somente aclamados. ${ }^{17}$ Portanto, a sagração seria um cerimonial inédito e esses procedimentos não teriam precedentes. E os responsáveis pelo cerimonial recorreram a quais instruções? Há duas hipóteses em questão. A primeira afirma um modelo

\footnotetext{
${ }^{16}$ Sobre José da Silva Lisboa, outra figura que se tornou exemplo de liberal por seus escritos econômicos, Buarque de Holanda acusa que sob a capa das citações revolucionárias e alegações de liberdade, desvela-se um conservador. Sérgio B. Holanda, "Apresentação", in J. J. da Cunha Azeredo Coutinho, Obras econômicas de J.J. da Cunha de Azeredo Coutinho, São Paulo, Companhia Editora Nacional, 1966. Ver também Antonio Penalves Rocha, A economia politica na sociedade escravista, São Paulo, Hucitec, 1996. Aqui colocamos em questão a idéia de que "princípios liberais" difundem-se, de modo uniforme, promovendo revoluções políticas e econômicas na passagem dos Setecentos.

${ }^{17}$ Paulo Mêrea, "Sobre a aclamação de nossos reis", Revista Portuguesa de História, Coimbra, 1962, p. 411-417.
} 
externo. Uma testemunha do evento, o plenipotenciário austríaco Barão de Mareschal, reporta que esse lhe lembrou outro, a sagração de Napoleão Bonaparte, ocorrida em $1804 .{ }^{18}$ Contudo, não há nenhum motivo evidente para que organizadores tenham se pautado pelo cerimonial napoleônico; pelo contrário, a figura de Napoleão era extremamente negativa na corte portuguesa, tanto por ter afrontado D. João VI, levando-o a refugiar-se no Brasil, quanto por ser entendido como um usurpador do trono. O próprio sermão da missa de sagração, feito pelo Frei Francisco Sampaio, repugna o ex-imperador da França: "um déspota, um soldado intruso na hierarquia dos reis (...) legítimo tirano pela usurpação dos direitos de todos os cidadãos"19 - do que se deduz que não se quereria ver esse epíteto de usurpador (do trono e de direito de cidadãos) vinculado a D. Pedro, ainda mais pelo cuidado com que se buscava então legitimar a separação política de Portugal.

Se o modelo do cerimonial napoleônico foi evocado em 1822, como observou o Barão de Mareschal, foi em verdade para contrastar com D. Pedro. Frente à imagem do usurpador, tratava-se, na sagração de D. Pedro, de sustentar a aclamação de um monarca legítimo, dando um duplo sentido à evocação de legitimidade. De um lado, recuperava a tese legitimista do direito hereditário ao trono, como fundamento admissível da coroação de D. Pedro - que faria parte da "hierarquia dos reis" por ser filho de um monarca. A própria escolha da aclamação ratificaria esta tese: $1^{\circ}$ de dezembro é a data em que se comemorava o início da dinastia de Bragança, ocorrido em meados do século XVII, com o fim do reinado da coroa de Espanha sobre Portugal. De modo que a autonomia política e a dinastia (e implicitamente o direito de sucessão real) são temas aqui recuperados para afirmar a legitimidade do reinado de D. Pedro. Por outro lado, afirmava o direito dos cidadãos (a liberdade

\footnotetext{
${ }^{18}$ Barão de Mareschal, Correspondência do Barão Wenzel de Mareschal (1821-1822), Revista do Instituto Histórico e Geográfico Brasileiro, Tomo 80, p. 131, 1916. Ofício de 3 de dezembro de 1822, n. 39, letra A. Esta hipótese foi endossada por Maria Ribeiro, que vincula este cerimonial e a sagração dos reis franceses. Cf. Maria Eurydice de B. Ribeiro, Os simbolos do poder, Brasília, UnB, 1995.

19 "Sermão que na cerimônia da sagração do Imperador D. Pedro I fez Fr. Francisco de Sampaio”, publicado n' O Regulador Brasílico, Rio de Janeiro, n. 21, 1822. Fr. Francisco de Santa Thereza de Jesus Sampaio foi padre-mestre da Capela Imperial. Era lente de teologia no Rio de Janeiro e figura notória na corte do Rio de Janeiro. Havia sido nomeado pregador régio em 1808, por D. João VI, foi examinador da Mesa de Consciência e Ordem em 1808, censor episcopal em 1813. Foi também redator do Regular Brazílico, de 1822 a 1823, e do Diário do Governo de 1823 a 1825 - cargo que foi assumido em seguida pelo cônego Januário da Cunha Barbosa. Cf. Blake, op. cit., vol III, p. 118-121.
} 
e a segurança individual) como um fundamento do regime que se inaugurava com D. Pedro, e que Napoleão havia infringido com o terror de sua espada; direito de cidadania que seria baseado no respeito à lei - numa "Constituição firmada sobre as bases do direito das gentes", nas palavras de Frei Sampaio - e garantido pelo monarca.

Uma segunda hipótese sobre os procedimentos utilizados considera o recurso ao Pontifical Romano, de fins do século XVI - um documento no qual constavam as regras que dispunham sobre a sagração dos reis. ${ }^{20}$ Cabe perguntar: por que se optou em utilizar os procedimentos religiosos de sagração na aclamação de D. Pedro? Evidentemente que alguns dos responsáveis pelo cerimonial poderiam conhecer a codificação - dentre eles, certamente, o bispo do Rio de Janeiro - mas a opção de utilizá-la é o ponto que colocamos em questão. Ao nosso entendimento, o emprego inédito apenas deixa mais exposto que o recurso a alguns procedimentos específicos possa ser uma opção estratégica. Neste artigo, defendemos a hipótese de que a alteração de procedimento de um cerimonial para outro, ou a reutilização dos mesmos procedimentos, não seria garantia a priori para deduzir a permanência ou continuidade dos fundamentos do poder político. ${ }^{21}$ Nesse sentido, o recurso à sagração na aclamação de D. Pedro I destoa ainda mais, por se tratar do evento de fundação do reino autônomo do Brasil. Ressalve-se, ainda, que há detalhes da sagração de D. Pedro que também não têm precedentes, caso das insígnias imperiais. O cetro utilizado pelo imperador em nada se assemelha ao utilizado por D. João VI -

\footnotetext{
${ }^{20}$ Esta possibilidade foi estudada por Guilherme Schubert, que comparou as instruções para sagração de D. Pedro I e o Pontifical Romano de sagração dos reis, ressaltando as similitudes nos procedimentos e fórmulas. Ver M. Guilherme Schubert, A coroação de D. Pedro I, Rio de Janeiro, Arquivo Nacional, 1973. Schubert informa que estas regras foram codificadas em 1596 pelo Papa Clemente VIII, completadas em 1644 por Urbano VIII e em 1752 por Bento XIV. Ibidem, p. 18. Ver também as regras prescritas para o ritual de sagração de 1822 reproduzidas ao final deste livro. Ibidem, p. 49-59.

${ }^{21} \mathrm{O}$ que também poderia ocorrer através da reutilização de procedimentos de cerimônias régias anteriores. Nesse sentido, uma análise superficial afirmaria imediatamente a continuidade de um modelo de política quando do emprego das mesmas instruções cerimoniais; isto é, partiria do pressuposto de que toda repetição formal traz consigo a afirmação do poder político segundo os mesmos fundamentos. Procuramos contestar este pressuposto no exame comparativo entre o cerimonial de aclamação de D. José I (alicerçado nos costumes e privilégios hereditários) e os de D. Maria I e D. João VI (pelas remissões a um direito divino). A reutilização de procedimentos semelhantes não significava então a definição do poder régio nos mesmos termos. Eduardo Romero de Oliveira, Salus populis: as transformações da politica (1818-1841), São Paulo, 2002. Tese (doutoramento em Filosofia) - Faculdade de Filosofia, Letras e Ciências Humanas, da Universidade de São Paulo, cap. I.
} 
nem o Pontifical Romano prescreve a sua forma. ${ }^{22} \mathrm{O}$ cetro foi confeccionado como uma grande vara, ao invés de um bastão, como foi o modelo de João VI. Mesmo a coroa de D. Pedro I em nada se assemelha à de D. João VI. Os integrantes da comissão do cerimonial conheciam esse modelo e, possivelmente, também os artífices fluminenses, mas não o seguiram. Trata-se, portanto, de refletir sobre a opção por um procedimento religioso num evento que busca afirmar não apenas o poder régio, mas também a autonomia política. A análise do cerimonial de sagração e coroação de D. Pedro I passa, portanto, por dois cuidados metodológicos: identificar a importância da religião e examinar a pertinência política do cerimonial, a partir do seu aspecto religioso.

\section{A função atribuída à religião no início dos Oitocentos}

Investiguemos primeiramente qual a função da religião na compreensão dos membros da Junta organizadora da aclamação de D. Pedro. Vale ressaltar que, desde fins do século XVIII, a religião passou a ser considerada também um meio de instrução pelo qual se "adquirem as virtudes de amar e temer a Deus, obedecer e amar aos soberanos”, segundo Francisco Gomes Villasboas, vigário capitular do bispado do Rio de Janeiro. ${ }^{23}$ Para este, a obediência era mais bem promovida pelas palavras e exemplos do que pela "coação" (pela força das armas). ${ }^{24}$ Este tema dos fins do ensinamento religioso foi retomado por Antonio Velloso Oliveira, num texto de 1822, sobre a Igreja no Brasil. Apresenta então a educação como a origens dos bens, e na educação religiosa, em especial, o soberano tem força "para dotar-se a si próprio daquela autoridade" necessária. ${ }^{25}$ Também no sermão de Frei Sampaio, a educação ensinava a respeitar aqueles que a religião "mostrava na ordem social, como os primeiros objetos

\footnotetext{
${ }^{22}$ Ver as reproduções da coroa e cetro de D. João VI no catálogo da Exposição D. João VI e o seu tempo. D. João VI e o seu tempo, Lisboa, Comissão Nacional para as Comemorações dos Descobrimentos Portugueses, 1999.

${ }^{23}$ Carta de Francisco Gomes Villasboas, vigário capitular do bispado do Rio de Janeiro ao Vice-Rei Fernando José Portugal (12.07.1805), Revista do Instituto Histórico e Geográfico Brasileiro, t. 16, 1853 , p. 359.

${ }^{24}$ Perspectiva encontrada também em José Bonifácio: "Miserável o país em que só os castigos fazem respeitar as leis e a pessoa do soberano! O clero que os podia [os povos] consolar e conter é uma das classes mais corrompidas e desprezíveis que há, geralmente falando, no Brasil". Miriam Dolhnikoff (org.), Projetos para o Brasil: José Bonifácio de Andrade e Silva, São Paulo, Companhia das Letras: Publifolha, 2000, p. 65. Apesar de crítico do clero e do cristianismo, José Bonifácio via na religião católica um papel essencial para a formação da nova monarquia brasileira.

${ }^{25}$ Antonio Rodrigues Velloso Oliveira, "A Igreja no Brasil”, Revista do Instituto Histórico e Geográfico Brasileiro, t. XXIX, 1866, p. 186. Este texto foi publicado originalmente em 1822, nos Annaes Fluminense de Sciencias, Arte e Literatura.
} 
do seu culto político". Na concepção de Antonio Oliveira, a autoridade estaria "firmada em leis sábias e prudentíssimas", isto é, todos devem ser instruídos nos seus deveres civis e religiosos, "cumprindo-os por força da educação". O aprendizado dos deveres religiosos está vinculado à obediência às leis e ao regente, como funções do conhecimento e da moral.

Efetivamente, existe uma concepção seiscentista de educação segundo a qual os deveres necessitavam ser reiterados freqüentemente, nos exercícios de sujeição promovidos pelas práticas religiosas de mortificação (encontrados nas procissões do período colonial) ou na resignação do espírito. Uma educação entendida como instrumentação moral da verdade, revelada por Deus e cogitada por homens iluminados pela Graça e autorizados pelo monarca. ${ }^{26}$ Uma concepção de educação igualmente encontrada nos cerimoniais oficiais da monarquia portuguesa, como aquelas celebrações da Ordem de Cristo, na qual os seus rituais associavam sujeição a Deus e submissão ao rei - cerimoniais nos quais se reiterava os deveres como cristãos e a sujeição enquanto súditos. As constantes mortificações do súdito produziam os eventos comemorativos de sua obediência ao monarca português.

Contudo, não é mais de uma educação revelada e praticada pela reiteração que tratam aqueles documentos do início do século XIX. Para Antonio Oliveira, a educação religiosa altera os costumes dos povos. Ao invés da força das armas, é a instrução que coloca o Estado e os homens em movimento: a educação promove o aumento da população e da riqueza; aumenta a sociabilidade e os casamentos, a "honesta emulação individual"; tira o homem da inércia e faz com que adquira amor ao trabalho, atuando como um estímulo: "os selvagens do Uruguai em poucos tempos de educação chegaram a um ponto de civilidade bem admirável, desprezando a inércia, tornaram-se trabalhadores". Assim, a educação transforma os homens, torna as nações mais humanas, sábias e respeitáveis; enfim, permite que se civilizem. E por instruir nos deveres e tornar os homens sociáveis, a educação religiosa adquiriu o papel de "primeira guia dos homens", chamando-os ao cumprimento das leis (religiosas e políticas) e regulando suas ações.

A propósito de nossa investigação, dentre todos os membros da Junta organizadora da sagração de D. Pedro, apenas de José Bonifácio localizamos alguns comentários breves e indiretos sobre a religião. Para o Andrada, os homens não são capazes pelas paixões, tanto quanto pelas necessidades, de criar

${ }^{26}$ Cf. João Hansen, A sátira e o engenho: Gregório de Mattos e a Bahia do século XVII, Campinas, Ed. Unicamp, 2004, p. 29-30. 
governos regulares. Esses governos apenas advêm da extensão da inteligência e da atividade individual. ${ }^{27}$ Segundo José Bonifácio, o homem é um autômato sem aquela faculdade e essa atividade, guiado tão-somente pelos prazeres grosseiros e pela inevitabilidade de suas necessidades. E depende da educação a conversão dos homens bárbaros (os índios) em homens civilizados, que vivem em governos regulares. Através do exemplo e dos benefícios, os homens fazem o uso da razão e possuem disposição ativa. A inteligência permitirá planejar a satisfação, conter os impulsos ou instintos, dar ânimo de trabalho ao homem. E a religião se valerá desta faculdade para fazer conhecer aos homens as leis divinas e as regras de justiça; portanto, ensinar o respeito. Assim, foi a catequização religiosa dos jesuítas, que permitiu aos índios alcançarem os elementos primeiros destas condições: o aprendizado dos cálculos e que se viva debaixo das leis do evangelho. ${ }^{28}$ São estes elementos que permitem produzir, comercializar e obedecer; através deles, pode-se ensinar os benefícios do uso dos bens e do dinheiro. A faculdade da razão dará constância àquela troca, estabilidade às relações, regularidade na convivência comum - devido à disposição de leis civis e de punição frente sua infração. A educação religiosa supõe a faculdade da razão como ponto de partida para o benefício individual, formar um governo regular e viabilizar a unidade política. De modo que a razão e a moral estariam entrelaçadas na educação, na concepção do Andrada; e assim se realiza a orientação religiosa e também a obrigação política. O exercício ritualístico da sujeição surge agora a partir do entendimento, e através dele a sujeição política é exercida sobre o corpo do devoto: os rituais definem um exercício relativo à faculdade do entendimento, através do conhecimento que o súdito detém dos seus deveres

\footnotetext{
${ }^{27}$ José Bonifácio de Andrade e Silva, "Apontamentos para a civilização dos índios bravos do Império do Brasil", in: Miriam Dolhnikoff (org.), Projetos para o Brasil, op. cit., p. 49.

${ }^{28}$ Observamos esta idéia também em Beccaria, cuja obra é freqüentemente citada pelos juristas portugueses e nos compêndios do ensino jurídico. Trata-se aqui da idéia de que a instrução (das ciências em geral) é fundamental à convivência social, mas uma instrução que permita realizar um "cálculo dos bens e dos males da existência". Cesare Beccaria, Dos delitos e das penas, São Paulo, Martin Claret, 2002, p. 101. Afora a apologia das luzes e da crença no poder da verdade, a obtenção de justiça passa pela proporção correta de leis e das penas, pela capacidade comparativa do sentimento alheio em relação ao nosso, na relação proporcionalmente inversa entre tribunais e desrespeito à lei. Tal argumentação sustenta-se, assim, num método matemático de exame das grandezas e numa atividade legislativa que funcionasse por este método, a fim de permitir a obtenção de felicidade. Para Beccaria, a legislação define-se como a "arte de proporcionar aos homens a maior soma de bem-estar possível”. A composição legislativa estaria fundamentada, portanto, num cálculo estatístico da felicidade. Esta concepção é que foi retomada por Bentham para conceber a idéia de utilidade como a "felicidade do maior número". De todo modo, ressaltamos que José Bonifácio não apenas enfatiza a instrução, mas também uma educação social fundamentada neste cálculo da felicidade; por isso o destaque ao aprendizado de aritmética.
} 
para com o monarca. Afinal, para José Bonifácio, a autoridade deveria estar respaldada numa obediência esclarecida, seja na instrução dos deveres civis, seja na educação religiosa.

Temos no sermão de Frei Sampaio, proferido durante o cerimonial, um documento que pode nos dar mais algumas indicações sobre o seu sentido religioso. A imagem de D. Pedro será apresentada aqui num entrelaçamento de elementos religiosos e políticos. Pela caracterização religiosa, o imperador é o ungido do Senhor, "aquele que recebe a sanção religiosa e por isto, a proteção divina". ${ }^{29}$ Por meio da unção recebem de Deus a marca de "seus representantes sobre a terra". E, por seus elementos políticos, D. Pedro é aquele que receberá a "sanção política", em gratidão por ter sido um dos primeiros e o mais zeloso "propugnador dos nossos direitos". Citando a história de várias nações antigas e contemporâneas, salienta a anarquia que atingiu aqueles povos em que o trono foi solapado na busca de uma idéia indefinida de liberdade. A conjunção destas duas caracterizações virá com a designação de D. Pedro como o "eleito": aquele que os céus concederam ao Brasil, para sua glória, mas também que "o povo descobriu na pessoa do monarca a garantia de sua fortuna" - tal qual o Rei Salomão, conforme a passagem bíblica comentada no sermão de Frei Sampaio. Esta fundamentação teleológica permitiria identificar nele o "augusto representante da nação".

Uma idéia de representação perpassa o sermão de Frei Sampaio: significa ao mesmo tempo "representante de Deus" e "representante da nação". Se a divindade detém a "soberania como um atributo de sua essência", e por isto pode revestir D. Pedro de um sagrado respeito, o frade também admite que ele tinha ascendido ao trono pela aclamação das províncias. Portanto, a divindade (fonte primeira de poder) e o povo, que ratificou a decisão daquele, deram as sanções religiosas e política para a eleição de D. Pedro como monarca do novo Império do Brasil. Enfim, a idéia de representação política traz consigo um forte teor religioso, na medida em que a sanção política confirma a decisão divina - aos moldes da idéia de que a dinastia regente materializa na dimensão temporal o desígnio de Deus. Caráter ambíguo da eleição de D. Pedro, que teria sido aclamado pela vontade do povo e ao mesmo tempo pela vontade divina - em que esta se materializa naquela.

O cerimonial de sagração vem ratificar aquele que fora escolhido por Deus e pelo povo como seu representante, marcando-o com o selo sagrado da invio-

29 "Sermão que na cerimônia da sagração do Imperador D. Pedro I fez Fr. Francisco de Sampaio”, publicado n'O Regulador Brasílico, Rio de Janeiro, n. 21, 1822. Reproduzido em Schubert, op. cit., p. 81-86. 
labilidade: "um dos maiores dogmas políticos, inculcado pela mesma religião, [...] penhor da paz, da prosperidade e da fortuna das Nações". A sustentação da monarquia constitucional passa pelo dever sagrado de resguardar sua pessoa, afirma o frade, que foi indicado pela Providência e ratificado através da unção real. A busca dos direitos dos cidadãos e a segurança individual jamais foram alcançadas através do banimento do trono e matança de reis, alerta o frade, citando a Grã-Bretanha de Carlos I e a França durante o regime bonapartista. Em contraposição a isso, colocam-se os da monarquia constitucional que se inaugura no Brasil: o respeito às leis, uma Constituição e a inviolabilidade real. Neste regime é preciso ter uma Constituição e um imperador que a faça sustentar: "lei e cetro são os penhores da nossa gloriosa regeneração". Portanto, o imperador seria "o centro donde sai a força" do regime, que transmite estabilidade à sociedade e faz respeitar as leis; e, conseqüentemente, garante a segurança individual e as riquezas, as condições de prosperidade e ordem social. A inviolabilidade dos reis seria uma das bases da monarquia constitucional, e a unção real prestar-seia justamente a sedimentar este dogma político, conclui o frade. Temos aqui, apontado neste sermão, três fundamentos políticos da nova monarquia que o procedimento religioso da sagração estabeleceu: legitimidade por direito hereditário; o caráter teleológico da representação política do imperador (em que a glória da nascente monarquia passaria necessariamente pela aclamação de D. Pedro, como realização da Providência); a inviolabilidade sagrada do monarca.

\section{A pertinência política dos procedimentos religiosos}

Um segundo cuidado metodológico é identificar a eficácia política do cerimonial da sagração, e faremos isso examinando contra quem foi proposta esta relevância da religião, e também contra quem foram contrapostos aqueles três fundamentos políticos, expostos nos sermão de Fr. Sampaio. ${ }^{30}$ Afinal, a

\footnotetext{
${ }^{30}$ Retomamos este cuidado metodológico das observações de Renato Ribeiro, que chama a atenção sobre as dificuldades de compreender Hobbes atualmente. Depois da vitória da imagem do Estado liberal, teria ficado difícil tolerar as considerações do jurista inglês sobre o poder político. Frente a este preconceito, alerta Ribeiro, seria preciso "entender contra quem Hobbes constrói o seu conceito de poder absoluto". Renato J. Ribeiro, Apresentação, in: Thomas Hobbes, Do cidadão, 2. ed., Trad. Renato J. Ribeiro, São Paulo, Martins Fontes, 1998, p. XXXIII. No mesmo sentido, vivemos hoje um momento em que a política é entendida como uma dimensão racional - e sobre essa característica deposita-se inclusive o elogio da democracia - e, portanto, fica difícil compreender o recurso à religião, no momento mesmo em que inaugura esta dimensão no Brasil monárquico. No lugar de explicar este recurso como um arcaísmo e decretar sua exclusão da análise política, propomos fazer a revisão do papel atribuído naquele momento à religião e verificar se ela também não atuaria então na definição do poder político.
} 
sagração foi proposta pela Junta organizadora do cerimonial num momento de embate entre o governo do imperador e o Senado da Câmara do Rio de Janeiro, um confronto que se formalizou na sagração e na Assembléia Constituinte, e foi exposto ao cônsul austríaco Barão de Mareschal, por José Bonifácio. Segundo este, julgava-se preciso afirmar a obediência ao imperador como sendo inevitável e superior. ${ }^{31} \mathrm{O}$ cônsul relata que a posição do governo era de que esta autoridade caberia a D. Pedro por direito hereditário, por ser da dinastia de Bragança, e não por reconhecimento de uma Assembléia soberana (único órgão legítimo da "vontade soberana do povo", como defendia José Clemente Pereira, Presidente do Senado da Câmara do Rio de Janeiro, na aclamação do imperador). ${ }^{32} \mathrm{O}$ governo não poderia deixar à Assembléia Constituinte brasileira que decidisse quem teria autoridade para governar - afirma Mareschal, a partir de conversas com membros do governo de D. Pedro I, como José Bonifácio. Diferente desta postura, outra defendia que a autoridade do imperador estaria assentada no direito divino, porque o ato religioso remeteria à Providência Divina a designação do D. Pedro: "este eleito para ser coroado Rei”, diz-se durante as unções.

De maneira que, de um lado, o cerimonial apresenta um poder político inviolável atribuído a D. Pedro, sustentado na sanção religiosa (a unção como marca do desígnio divino), na sanção política (na "aclamação repetida em todas as províncias") e no direito hereditário do imperador ao trono do Império. Por outro, a realização de uma Assembléia Constituinte procura defender a precedência de um Poder Legislativo, posição fundamentada no argumento de que a vontade da nação se expressaria na confecção das leis pelos cidadãos reunidos em Assembléia. Havia, portanto, um potencial conflito de autoridade entre o poder do Imperador D. Pedro I e o da Assembléia: entre o poder intocável do imperador e o poder dos deputados constituintes para instituir a organização social. E esta divergência colocava em debate a restrição às funções dos poderes e as condições de exercício de cada um, e questionava particularmente se o poder real estaria alheio à confecção das leis ou não.

\footnotetext{
${ }^{31}$ Mareschal, op. cit., p. 107.

${ }^{32}$ Citado em Max Fleiuss, Sessão Especial, em 12 de outubro de 1922, Revista do Instituto Histórico e Geográfico Brasileiro, 1922, p. 352. Também segundo Mareschal, José Bonifácio entendia que "le Prince se trouverant Empereu sans qu'elle [a Assembléia Constituinte] eut à y intervenir et par une autorité supérieure, émanant de la volante directe du Peuple, que cette assemblée feroit des lois, mais ne seroit point admise à représenter toute la souveraineté, le souverain faisant une partie essentielle de la réprésentation nationalle...”. Mareschal, op. cit., p. 115, Ofício de 19 de outubro de 1822, no 32, letra B. Esta perspectiva do monarca como representante da nação era antiga, e o próprio D. João VI foi assim compreendido.
} 
O que estava em questão era uma delimitação dos poderes que legalmente comporiam o Estado imperial.

Por causa desta situação de múltiplas confrontações, ressaltamos ainda já ter havido dois momentos de afirmação do poder político de D. Pedro. Afinal, antes do cerimonial de sagração houve o de aclamação, em 12 de outubro. Se a sua autoridade já estivesse bem fundamentada neste último, por que uma outra cerimônia? Além disso, a coroação poderia ter sido concebida aos moldes da aclamação de D. João VI, que ocorrera poucos anos antes; porém, a comissão responsável por elaborá-la optou por um cerimonial religioso, acrescentandolhe elementos daquela aclamação. Em verdade, é como se tivessem dividido o antigo cerimonial português de aclamação em duas partes: uma declaração da aceitação do título de imperador feita por D. Pedro, em outubro; e o cerimonial de coroação, em dezembro. Se o poder político atribuído a D. Pedro I fosse idêntico ao de D. João VI, tivesse os mesmos fundamentos, por que estabelecer um cerimonial distinto? Podemos supor que a cerimônia de sagração e coroação de D. Pedro I foi um esforço de instituição de sua autoridade, frente à Assembléia Constituinte que fora convocada em julho de 1822. ${ }^{33}$

Convém observar que o poder político de D. Pedro I tinha que se legitimar também sobre outras forças: a de D. João VI e as cortes portuguesas. Frente ao monarca, seu pai, e contra as cortes portuguesas, justificava-se a aclamação de D. Pedro I sobre o reino do Brasil, alegando o direito de sucessão real e por estar o monarca D. João VI “aprisionado" pelas cortes, sem poder de decisão, e, portanto, destituído de soberania. ${ }^{34}$

\footnotetext{
${ }^{33}$ Este caráter sagrado do rei já era constantemente criticado em panfletos de 1821 por defensores de um "constitucionalismo", que denunciavam o "poder despótico" como sagrado, conforme relata Lucia Neves, op. cit., 1992, p. 173.

${ }^{34}$ Cf. Instruções a Felisberto Caldeira Brant Pontes, datada de 12.08.1822, para negociar com a Inglaterra o envio de oficiais e tropas armadas ao Brasil. Citadas por Tobias Monteiro, História do Império, Rio de Janeiro, Briguiet, v. I, 1939, p. 325. A mesma tese do Rei D. João VI "cativo" das cortes portuguesas será alegada meses depois aos ingleses para justificar a declaração de emancipação total do reino de Portugal. Alegação de catividade de D. João VI, expressada também ao cônsul austríaco. Ver Mareschal, op. cit., p. 107, 1916. Ofício de 2 de outubro de 1822, n. 29. Esta tese retornará no processo de negociação com Portugal, em 1825, para o reconhecimento da independência política do Brasil, quando sustentará então a afirmação do "jugo tirânico" das cortes de Lisboa, como um dos motivos alegados à separação política. Vide Oliveira Lima, História diplomática do Brasil, Rio de Janeiro, Garnier, 1901, p. 318. Também em Portugal o grupo mais ferrenhamente monarquista alegava esta tese do aprisionamento de D. João VI. Por exemplo, Carlota Joaquina, ao se recusar a assinar a Constituição portuguesa de 1823. Vide carta da Rainha D. Carlota a El-Rei, transcrita em José da Silva Lisboa, "Apêndice à Crônica Autêntica da Regência do Príncipe D. Pedro de Alcântara, Anexa à História dos principais sucessos políticos do Império do Brasil, por José da Silva Lisboa (Visconde de Cairu), Rio de Janeiro, 1829", Revista do Instituto Histórico e Geográfico Brasileiro, t. 66, 1904, p. 244.
} 


\section{Os fundamentos políticos da sagração}

Quando o cerimonial da coroação foi definido, a comissão recorreu a procedimentos religiosos, em que a devoção interagia com a sujeição política. Note-se que tanto para os defensores do direito hereditário quanto para aqueles que aludiam ao direito divino, a opção de fazer a coroação baseada num cerimonial eclesiástico permitia a afirmação do poder político de D. Pedro como um poder supremo, superior ao da Assembléia. E se o objetivo político destes procedimentos é ligar autoridade e obediência, a religião estabelecia este vínculo, alertando todos para tomarem ciência de seus deveres e do respeito devido ao monarca. "Exortar os nossos filhos à sã boa ordem e obediência aos nossos superiores", diz Frei José, Bispo de Mariana, e assistente do capelãomor, no cerimonial. ${ }^{35}$

A sagração do novo imperador recorre ao "dever de consciência" como depositário do respeito que lhe é devido. Quando o sermão de Frei Francisco de Sampaio, pronunciado na sagração, foi publicado no jornal O Regulador Brasileiro, teve uma epígrafe muito significativa: "Établissons nos institutions sur l'amour des citoyens, et sur leur volanté eclairée" (estabeleçamos nossas instituições sobre o amor dos cidadãos e sua vontade esclarecida). É preciso compreender neste cerimonial os desígnios divinos, diz o Frei, ouvindo o que Deus nos diz através de nossa consciência. A consciência e a razão do homem expressam a lei e a autoridade suprema de Deus. O cerimonial de sagração é o momento de lembrar aos súditos o respeito devido ao imperador. É na consciência do devoto e do cidadão, no seu entendimento, que se joga a questão da obediência. Esta obediência se sustém agora na lei da razão, que "impõe ao homem certas obrigações para com Deus, para consigo, e para com os outros homens". O sermão propõe o entrelaçamento dos desígnios divinos revelados ao devoto com a vontade racional dos cidadãos, da proposição religiosa de obrigação de consciência com a idéia iluminista do homem guiado pela razão.

Ao comentar as garantias para que um povo encontre sua felicidade e seus direitos sem cair nas desgraças da guerra civil e do despotismo, Frei Sampaio aponta, além do respeito às leis, "uma Constituição firmada sobre as bases do direito das gentes". Este direito das gentes era, conforme encontrado em vários textos portugueses do período, "a coleção de leis que a Natureza regulou a ação dos povos livres” e as obrigações com que os ligou para seus

35 "Non solum propter temorom, sed propter conscientiam", cita Frei José. Pastoral a propósito da coroação, apud Schubert, op. cit., p. 45. 
interesses comuns e o bem universal da Humanidade. ${ }^{36} \mathrm{O}$ direito das gentes está fundamentado nas disposições da Natureza, que os homens podem conhecer através do recurso à sua "razão natural". Enfatizar um texto constitucional neste direito das gentes era indicar parâmetros à redação do texto legislativo: os direitos dos reis devem fundamentar-se na lei natural e a fonte exclusiva desta lei é a natureza humana; ou melhor, aqueles princípios de uma razão natural que o autor da natureza escreveu no coração do homem. ${ }^{37}$ Ressaltamos que esta razão não é simplesmente o puro exercício racional de cada deputado, mas que esta atividade passa por princípios bem determinados, encontrados na natureza do homem, na religião, na ordem natural das coisas e na conduta uniforme dos reinos - comenta Frei Sampaio. Se os reinos seguirem estes princípios, isto resultaria em garantir a "segurança dos povos e a felicidade das monarquias". Quando se distancia destes princípios, como os povos tinham feito nas últimas décadas, isto lhes traz a anarquia social e a perda dos direitos. E dentre estes princípios, postos pela natureza e pela religião, está o dogma da inviolabilidade dos reis, "penhor da paz, prosperidade e da fortuna das nações". O novo império do Brasil deve erguer-se justamente sobre aquelas máximas e este dogma, bases à elaboração da Constituição.

${ }^{36}$ Estatutos..., Livro 2, Tit. 3, cap. 6, §5. Consulte-se, a título de exemplo, a obra de Filipe Coelho, que comentava a legislação do reino português segundo princípios de direito natural. Filippe José Nogueira Coelho, Principios do direito divino natural, publico universal, e das gentes, adoptados pelas ordenações, leis, decretos..., Lisboa, Francisco Borges de Souza, 1773. Filipe Coelho explica que o direito das gentes é aquele direito que regula as ações dos reinos ou entre elas, no âmbito diplomático, comercial ou nos conflitos. Ibidem, p. 7. O jurista português sustenta as definições de direito natural a partir de Pufendorf, citando o De jure naturae et gentium, livro 2, cap. 3, § 22. E para a noção de direito das gentes cita Grócio, Hobbes, Christianus Wolff e De Wattel. Evidentemente, a expressão "direito natural" é antiga e aparecia já nas ordenações manoelinas, e tendo sido associada ao direito divino quando este jusnaturalismo era de caráter eminentemente teológico. Aquela expressão "direito das gentes" provém do direito romano, onde se concebia o ius gentium como um direito observado por todos os povos e estabelecido pela "razão natural" (uma ordem cosmológica), e passou no período medieval a ser entendida como sinônimo daquele direito natural pelo qual todos os homens participam da natureza criada por Deus. A expressão foi retomada por Grotius para pensar um direito superior aos Estados, que regula suas relações e cujos ditames estão conformes com a natureza racional do homem. Na caracterização da tradição tomista, o ius naturale era relativo à essência de Deus, com sua participação da lei eterna, enquanto que nos modernos filósofos, os princípios de lei natural são derivados da essência da natureza humana, através do recurso ao hipotético "estado natural" do homem. Se o direito das gentes era concebido na Antigüidade clássica como um direito fundado na natureza, foi redefinido pelos jusnaturalistas modernos como um direito entre os reinos e baseado na natureza humana, fundamentado, portanto, num "direito natural" do homem e não na essência de Deus. Cf. Norberto Bobbio, Positivismo jurídico, São Paulo, Ícone, 1995, p. 17.

${ }^{37}$ Estatutos..., op. cit., Livro I, Tit. 3, cap. 5, § 26. 
Consideramos que o sermão de Frei Sampaio opera com princípios de uma reflexão política jusnaturalista, vinculados ainda com pressupostos religiosos - como o da vontade divina (causa última da existência universal e da natureza social), que é possível de ser conhecida pelo auto-exame de nossa consciência. Em função disso, a idéia de consciência toma um duplo sentido: é racional, permitindo deduzir tais princípios pelo exame da natureza das coisas e dos homens; mas também é uma consciência religiosa, na qual se revela a eloqüência sublime e divina. Observamos nesta reflexão jusnaturalista um caráter eminentemente antropológico, ainda que articulado a elementos religiosos. Trata-se, aliás, de uma reflexão filosófica "racional e moral" - paralela àquela que estaria sendo exposta nas cadeiras de Filosofia, ensinadas por frades como Januário da Cunha Barbosa.

Os Estatutos da Universidade de Coimbra já haviam estabelecido uma relação entre os preceitos racionais e religiosos - "os meios de salvação eterna consistem na prática das regras que a Natureza ditou para a direção das ações humanas". ${ }^{38}$ Mas ressalte-se que tais afirmações se inserem no quadro geral de orientações de moral religiosa dos Setecentos; e correspondem aos parâmetros tomistas de que o homem deve submeter-se a uma lei eterna, seja orientando sua crença pela lei divina revelada nas escrituras ou apreendendo na lei natural sua participação na lei eterna e no universo criado por Deus. Uma grande alteração desponta nas considerações presentes no sermão de Frei Sampaio: é a lei natural que prepondera, como existindo e sendo conhecida a partir da faculdade da razão; lei natural dedutível racionalmente através do exame da história, da Natureza e da religião. Um exercício dedutivo que, a partir da condição humana, leva a concluir sobre quais as instituições políticas coerentes com a história humana e os desígnios divinos, que permitem atingir os fins da sociedade e do espírito humano. Enfatiza-se ainda que esta lei é fundamento do poder político do imperador e de toda a dimensão política - ratificando sempre o poder daquele como supremo na dimensão temporal.

O que se propõe então na sagração de D. Pedro I é que tanto a autoridade do imperador quanto o próprio poder da Assembléia Constituinte estariam baseados naquela "razão natural", própria de todo homem, e que exigia uma obediência absoluta às leis. Nas discussões da Assembléia Constituinte irá se recuperar esta noção de obediência política porque se reconhecia que a fonte efetiva da autoridade política estava depositada no poder monárquico. Houve

${ }^{38}$ Estatutos..., Livro I, Título 3, cap. 1, § 46. 
já na sagração uma concordância tácita sobre este ponto, pois se considera que apenas pelo recurso à razão são produzidas leis. Contudo, na Assembléia, retoma-se aquela noção porque queria suprimir do monarca o poder de declarar uma razão política, reduzindo-se a fazer obedecer à Constituição por ser redigida pela Assembléia; ${ }^{39}$ isto porque prepondera nela o princípio de que a origem da autoridade das leis não está concentrada tão-somente no monarca: ela passa agora pela Assembléia de cidadãos reunidos, dos representantes eleitos.

Enfim, se os deputados da Assembléia detêm algum poder político e propõem instituir uma nova organização política, eles devem exercer este poder pelo recurso à razão natural, isto é, nos limites que lhe permite este direito natural. Daí uma diferença importante entre esta razão, reconhecível na nascente monarquia constitucional, e outra, encontrada na antiga monarquia portuguesa. Enquanto a anterior era a razão que se concretizava tão-somente na voz do rei, através de seus alvarás e decretos, agora é uma raæão natural do homem: universal, presente em todos os homens e guiando internamente suas vontades. A partir desta razão é que se constitui, na dimensão política, uma vontade geral racional e soberana, que é expressa por leis produzidas pela representação nacional (leis redigidas pelos representantes eleitos à Assembléia Geral, sancionadas e sustentadas pelo imperador). Esta "razão natural" é, portanto, o predomínio da faculdade do entendimento na direção da vontade,

${ }^{39}$ Uma vez reunida, a Assembléia, em março de 1823, procurou afirmar sua total superioridade na promulgação dos artigos constitucionais, sem requisitar a anuência do Imperador D. Pedro I. Procurou depositar apenas em si mesma a expressão daquela vontade racional e soberana, mas não excluía a figura do imperador do campo da política, porque a ele cabe fazer cumprir a Constituição. A Assembléia Constituinte e o imperador entravam seguidamente em conflito sobre a questão da sanção dos artigos da Constituição; porém, isso não atingia o ponto consensual: era preciso garantir a obediência política, e para isto a figura do monarca era essencial. Os atritos resumiam-se à participação ou não do imperador na confecção do código constitucional, o que seria possível através da sua sanção. Esse impasse seguiu-se por todos os meses em que a Assembléia esteve reunida. Desde o discurso inicial, D. Pedro I afirmava que as leis seriam feitas pela Assembléia e pelo imperador, isto é, que o Poder Legislativo estava dividido entre o monarca e a Assembléia Legislativa. O impasse retornaria em setembro, quando o projeto constitucional enviado a D. Pedro I lhe desagradou - projeto em que se desconsiderava a sanção imperial para que a Constituição entrasse em vigor quando terminada. A tensão seria contornada com a promessa de que aquele artigo seria revisado, feito pelo então Ministro do Império e também deputado constituinte Carneiro de Campos. Contudo, a tensão aumentou nas semanas seguinte de outubro, quando discursos inflamados de deputados continuaram a questionar a sanção imperial. O desfecho veio em dezembro, com a dissolução da Assembléia Constituinte pelo imperador. Ver Octávio Tarquínio de Souza, História dos fundadores do Império do Brasil, Rio de Janeiro, José Olympio, 1972, v. III, t. II, p. 125. 
base da liberdade individual e política humana, mas uma faculdade que se exerce estritamente conforme os princípios de direito natural (e dentre os quais está o dogma da inviolabilidade real). A cerimônia de sagração de D. Pedro I concebe então uma ordem política que deve se submeter a tais condições gerais, como uma exigência de governo político que segue moderado pela razão natural. A Assembléia Constituinte não recusará esta exigência, mas a reforçará, inclusive. Ela irá requisitar para si esta orientação do governo político e reconhecer nela mesma a formulação de uma razão política.

\section{Elementos simbólicos do cerimonial de sagração}

Tais considerações permitem-nos observar alguns outros aspectos do cerimonial da sagração de D. Pedro I. A descrição do imperador sagrado, presente no sermão, é decisiva para avaliarmos os elementos simbólicos do cerimonial. D. Pedro surge como "ligado aos interesses da nação" e "Defensor da Constituição" - são as duas características relevantes do novo monarca. Sendo parte da Nação, está fortemente atado aos seus anseios e destinos. Pode comandá-la para a sua felicidade porque tomou para si os ideais deste povo e os dirige na sua busca de liberdade e afirmação de seus direitos. Daí o imperador ser também o "Defensor da Constituição", como aquele que se coloca na linha de frente da batalha disposto a lutar contra as forças inimigas em prol da proteção dos direitos de seus povos; "direitos invioláveis" e que estariam transcritos na Constituição. Uma imagem de "propugnador dos nossos direitos", apresentada pelo frade, em que a nação surge identificada nos "direitos invioláveis" que D. Pedro acolhe como também seus e se dispõe a defender. Esta imagem do soldado pronto para o conflito está presente no cerimonial, pois D. Pedro veste o uniforme militar sob o manto real: assim desfilou no cortejo até a igreja e apresenta-se durante o cerimonial. De modo que o seu poder político se sustenta na imagem de um governo protetor, em que desponta a idéia de defesa dos direitos constitucionais - contrastante com uma imagem setecentista do rei-salvador do reino e da alma de seus súditos.

E não é apenas o fato de D. Pedro I estar vestido com o uniforme militar que permite aludir à imagem do rei-soldado, mas também as insígnias que $\mathrm{D}$. Pedro leva consigo. Estas permitem compor a cena do imperador indo para a batalha, "marchando à sua frente com a tábua da Lei em uma mão, e noutra com a vara da Justiça"; isto é, com a Constituição e o cetro - conforme o sermão de Frei Sampaio. Evidentemente há um anacronismo nesta figuração, 
pois D. Pedro não estava durante o cerimonial segurando a Carta numa das mãos, já que esta virá a ser redigida posteriormente. Porém, ela surgiu simbolicamente no juramento, momento central do cerimonial, quando a fórmula do juramento lhe atribui a função de defesa da Carta. ${ }^{40}$ Daí afirma-se que o poder político do imperador está não apenas nela fundamentada, mas a traz consigo no exercício de seu poder.

Observamos também que D. Pedro sustém um bastão durante a cerimônia (o cetro imperial), que não é idêntico ao cetro real de D. João VI - com a forma de um pequeno bastão curto e símbolo tradicional do poder régio em Portugal. Aquele de D. Pedro I assemelha-se, isto sim, ao báculo - o cajado dos bispos e indicativo da função pastoral, daquele que guia os povos para a salvação das almas - uma semelhança que Sampaio ressalta logo no início do sermão da sagração. E como Cristo, na imagem do Bom Pastor, está disposto a dar sua vida pelos que conduz. Sampaio ressalta também o dom do imperador: sua eleição pela Providência para o reinado do Império do Brasil. Ora, se a coroa imperial não tem a forma tradicional de coroa régia, assemelha-se, porém, à mitra: barrete usado pelos bispos como insígnia do poder de jurisdição no bispado, que foi concedido como um dom, um poder ofertado pela Providência. ${ }^{41} \mathrm{O}$ báculo e a mitra são insígnias daquele que detém um poder de reger e julgar, derivado da Providência divina e que se exerceria com propósito de salvação espiritual dos homens. Destacamos assim algumas remissões formais entre as insígnias episcopais e as imperiais, que o sermão de Sampaio estabelece direta ou indiretamente; e que as faz para afirmar um poder de salvação exclusivo do imperador: a defesa dos direitos constitucionais.

Note-se primeiramente que na imagem do imperador com as insígnias está simbolizado aquele que é o ungido de Deus, um "de seus Representantes sobre a terra”, como descreve o próprio Frei Sampaio. O imperador apresenta-se como um sacerdote, agora sagrado, e que detém o poder de justiça para fazer valer os direitos e liberdades de seu povo - o sermão do Frei Sampaio alude

\footnotetext{
${ }^{40}$ Notamos, aliás, que a segunda parte do procedimento de juramento é feito pelos fidalgos presentes e, o que é mais importante, aos representantes das Câmaras. Trata-se de ratificar a obediência ao novo monarca e também ao sistema constitucional do regime. Esse momento do cerimonial de sagração de D. Pedro I foi reproduzido por uma ilustração de Debret, coroação de D. Pedro I.

${ }^{41}$ CF. Udo Becker, Dicionário de símbolos, Trad. de Edwino Royer, São Paulo, Paulus, 1999, p. 292. Ver também Gerd Heinz-Mohr, Dicionário dos símbolos: imagens e sinais da arte cristã , Trad. de João Rezende Costa, São Paulo, Paulus, 1994, p. 52-53; p. 276-278. Vocábulos "bastão", "pastor" e "mitra", respectivamente. Aliás, aqueles bispos que têm direito à mitra portam um cajado curvo, voltado para fora. Cf. Heinz-Mohr, idem, p. 251.
} 
à "vara da Justiça". Em segundo lugar, são direitos que, como a Constituição a ser redigida, repousam nos "direitos das gentes", isto é, no direito natural. Entrecruzam-se aqui os direitos naturais dos homens e a ordem universal posta por Deus, aqueles direitos refletindo esta ordem e reafirmando-se. Assim, defender os direitos dos povos é também fazer cumprir a Lei suprema estabelecida pela vontade de Deus. Representante divino na terra, o imperador é também defensor da Constituição, dos direitos e liberdades da nação: operador de justiça humana e divina simultaneamente. Daí as imagens de sacerdote e soldado se superpõem de maneira coerente no cerimonial da sagração; cerimonial em que o princípio da inviolabilidade do monarca adquire tanto caráter sagrado, pois está posto na Lei de Deus, quanto também um valor político, já que é centro de unidade e defesa dos direitos constitucionais. De maneira que o poder político de D. Pedro fundamentará sua autoridade, tanto nos próprios princípios de uma razão natural - aos quais a redação da Constituição deve igualmente se submeter - quanto também na soberania divina, a que todo ser vivente e criatura de Deus está incondicionalmente sujeito.

Há uma dubiedade evidente na cerimônia, em que o sagrado e o político se articulam. A imagem do imperador como defensor constitucional reúne tanto caráter de realizador dos desígnios divinos através do poder político - aproximando esta imagem daquele outra setecentista do rei-salvador - quanto representante da vontade dos povos que elegeram D. Pedro - numa terminologia coerente com o ideário da Revolução francesa. Uma primeira indicação desta articulação é a dupla eleição (divina e popular) aludida por Frei Sampaio e pela qual estaria se coroando D. Pedro. O fato de que a figura do imperador seja assim composta leva-nos a descartar uma análise pautada pela simples contraposição da imagem do rei-salvador ao ideário revolucionário. O que temos, ao contrário, é um entrelaçamento paradoxal entre a imagem do rei-salvador e símbolos de ruptura com um poder monárquico "absoluto" (pela alusão "a tábua da lei" constitucional), entre a teoria do direito divino (o governante como expressão da vontade de Deus) e o moderno conceito de representação política (o governante como expressão da vontade popular). Por isso, a dimensão política nesses anos 1820, no Brasil, é o resultado destes elementos entrecruzados, nos quais a alteração e a mudança são difíceis de identificar.

Além disso, a elaboração desta simbologia é um desdobramento direto das disputas políticas por legitimidade. Observamos que a coroa do impera- 
dor é distinta daquela utilizada por D. João VI, na aclamação, em 1818. Os integrantes da comissão do cerimonial de sagração conheciam este modelo, e provavelmente também os artífices fluminenses encarregados de fundir a coroa do império, mas não o seguiram. Em verdade, a coroa do imperador reproduz a "coroa imperial portuguesa" - uma coroa de forma cônica, distinta da coroa real. Esta, assim como a coroa régia, era utilizada em condecorações de ordens régias - como, por exemplo, numa peça honorífica da Ordem da Cruz de Sant'Iago, de 1812, concedida pelo monarca português, ${ }^{42}$ o que nos leva a supor a utilização de um modelo preexistente.

José Bonifácio, membro da Comissão de Organização do cerimonial, lamentava que D. João VI já não tivesse se tornado o monarca de dois reinos desde 1816, e tomado os títulos de "Rei de Portugal" e "Imperador do Brasil", mas que ao invés tivesse vindo a "criar um reino ilusório", ${ }^{43}$ dando a entender que um Estado soberano do Brasil, anterior às cortes e à regência de D. Pedro, já se anunciava há alguns anos. Consideramos assim que foi transposta para o âmbito das insígnias esta distinção entre os títulos, e no qual estava implícita a preexistência daquele Estado separado de Portugal. Além disso, José Bonifácio alegava que D. Pedro "tomava o título" deste Estado do Brasil: por direito hereditário, contrariamente às ordens das cortes portuguesas, porque o rei estaria cativo. O símbolo imperial seria assim diplomaticamente importante porque distinguia entre a regência sobre a coroa de Portugal (tomada pelas cortes), e a coroa do Brasil (mantida na dinastia Bragança).

Mas tem também uma eficácia na disputa política local, porque D. Pedro "tomava o título" e, independente da Assembléia Constituinte, por vontade superior. Afinal, segundo José Bonifácio, "eles se entendiam saindo do estado natural e o título de imperador era tomado como designando o chefe de um vasto império" (grifos nossos). Em outras palavras, na terminologia jusnaturalista da época, de origem latina, o soberano (Imperanti) é o chefe do Estado (Imperio), cujo pacto de origem une monarca e súditos, e têm suas regras ditadas pela

${ }^{42}$ Esse exemplar está reproduzido em $D$. João V e o seu tempo, op. cit. Se a coroa imperial materializa o "projeto político de um poderoso império" de D. Rodrigo Coutinho, conforme a tese de Maria de Lourdes Lyra, isto não pudemos confirmar durante a pesquisa. Este pendente em particular pode ter sido concedido por mérito nas lutas contra a ocupação francesa. De todo modo, o que importa são as reativações de conceito, símbolos e alusões a um Império, apesar de distintas.

${ }^{43}$ Barão de Mareschal, op. cit, t. 80, p. 114-115, 1916. Ofício de 19.10.1822, n. 32 - letra B. 
Natureza. ${ }^{44}$ Assim, para o Andrada, o "verdadeiro pacto que se forma entre o povo e o soberano" é anterior à Assembléia, e se manifesta no título de imperador tomado por D. Pedro, de modo que a terminologia jurídica da época acaba transposta para o símbolo da coroa imperial. ${ }^{45}$

A coexistência destes símbolos no cerimonial caracteriza o poder imperial de D. Pedro como um poder imperial supremo que tem por objetivo a salvaguarda de direitos constitucionais, definindo o imperador como governante eleito por Deus, ratificado pelo povo e "filho de reis". E também alusiva ao estabelecimento daquele vínculo é a formulação de que, se os cidadãos examinarem suas consciências, encontrarão ali desígnios divinos - os quais confirmam a escolha daquele. Este governo protetor que surge então traz como seus fundamentos a vontade de Deus e a "vontade dos povos", reunidos no poder político de D. Pedro. Enfim, a imagem do imperador-defensor faz-nos considerar a hipótese de uma articulação entre o dever real de salvação e a vontade da nação.

\footnotetext{
${ }^{44}$ Nestes termos encontrava-se a referência ao monarca e seu poder, por exemplo, sobre o direito de revolta, no manual usado na disciplina de Direito Natural, no curso de Direito de Coimbra, desde 1772 : "[...] quippe Imperri Populus excipere haud potuit, se rect solum Imperanti parere velle [...]". Carlo A. de Martini, Positiones de iure civitatis, Lisboa, p. 166 apud Dias, op. cit., p. 99, nota 3. Escrevia-se no Compêndio Histórico, que "esta admirável disciplina [o direito natural] notifica também e prega altamente aos vassalos a obrigação de serem fiéis e obedientes aos seus soberanos, de observarem as leis, e de contribuírem para as necessidades públicas do estado fazendo-lhes ver que todos estes ofícios lhes são impostos pela natureza [...] As sólidas regras e os inalteráveis princípios da mesma disciplina confundem inteiramente as duas perniciosas seitas dom ímpios monarcómacos e maquiavelistas [...]. As mesmas regras e princípios estabelecem também e regulam os limites do império para se não confundirem com as do sacerdócio". Compendio Histórico, Lisboa, Regia Officina Typografica, 1771, p. 210-211.

${ }^{45}$ Já se atribuiu a José Bonifácio o comentário de conceder o título de imperador ao regente aclamado D. Pedro, que poderia ser facilmente reconhecido pelo povo - já que nas festas do Divino Espírito Santo, no Rio de Janeiro de então, escolhia-se o "Imperador do Divino". Não encontramos documentação comprobatória desta atribuição. Apesar disso, defendemos que este cerimonial pode ser compreendido dentro de uma cultura política letrada luso-brasileira. Por um lado, ressaltamos que a sagração régia seja um cerimonial pautado em regras canônicas, como comprova Guilherme Schubert, sem relação com as práticas religiosas das festas populares do Divino. Mesmo a importância da religião assume uma função racional de instrução cívica, como destacamos em José Bonifácio. E, por outro, há menções à teoria política jusnaturalista, tanto no sermão de Frei Sampaio quanto na argumentação do mesmo ministro junto a Mareschal. Nesse sentido, a comunicação da figura do rei talvez não seja tão "ambivalente", o vocabulário de festas nem tão comum e o sentido das palavras nem tão amplos como supõem os estudos atentos ao vocabulário político do período. Ver Iara Souza, op. cit, p. 308.
} 


\section{Algumas considerações sobre a dimensão política no início da década de 1820}

Não há de nossa parte nenhuma pretensão antropológica de análise dos ritos, para deles declinar uma estrutura da ritualística política. Nem tampouco queremos sistematizar ao final alguns vocábulos de simbologia política. Enfim, nosso questionamento está voltado para a eficácia simbólica do cerimonial - o que extrapola a mera "tradução" dos símbolos, pois buscamos examinar os efeitos táticos e não o significado extemporâneo de símbolos da realeza. Assim, observamos como, na sagração de D. Pedro I, foi atribuída ao imperador sagrado uma autoridade que ultrapassava o julgamento humano e que não poderia ser questionada pela Assembléia Constituinte. Este procedimento religioso de sagração recuperava a teoria do direito divino, que pelo menos desde a aclamação de D. Maria I era alegado para fundamentar o poder real. E, ao mesmo tempo, privilegiavam ainda os procedimentos religiosos como um dos principais dispositivos a um controle das condutas humanas. A realização do cerimonial da sagração afirmava o poder político como uma dimensão superior, cuja autoridade e a obediência são absolutas. E nem a Assembléia Constituinte deveria colocar em dúvida este fundamento imperial do poder político. Enfim, a política no Império do Brasil surge como uma dimensão de produção e distribuição de poder, organizada pelos conceitos de razão e obediência.

Observamos aqui que a propalada laicização moderna não significou um expurgo da terminologia ou conceitos de matriz religiosa, como faria sugerir o embate entre autores da monarquia portuguesa e a Igreja. Tratou-se mais de um esforço de esvaziamento do poder de jurisdição da Igreja, mas não de uma simples eliminação de conceitos católicos, de suas máximas ou identificação de finalidades. Eles estão entrelaçados agora com outras noções e ajudam a compor uma formulação política dentro da tradição tomista. Nossa análise do cerimonial da sagração de D. Pedro I procura destacar que há outra teoria política com impacto maior dentro deste processo, porque opera a partir daquela tradição, ainda que seja para redefini-la a partir do jusnaturalismo alemão setecentista. No lugar das idéias "regicidas" de Rousseau, nossa tese é de que outro jusnaturalismo mais reacionário foi concebido em Portugal, no período pombalino, ligado às idéias que definiram o poder régio e legitimavam o despotismo dos reis portugueses do final dos Setecentos. ${ }^{46}$

\footnotetext{
${ }^{46}$ Seguimos aqui considerações e possibilidades de análise abertas por Lourival Gomes Machado, O Tratado de Direito Natural de Tomás Antonio Gonzaga, São Paulo. Ed. Universidade de São Paulo, 2002; Francisco Calazans Falcon, A época pombalina, São Paulo, Ática, 1982; Antonio Hespanha, A história do direito na história social, Lisboa, Livros Horizonte, 1978; e José da Silva Dias, Pombalismo e teoria política, Cultura, Lisboa, n. 1, p. 45-114, 1982.
} 
No cerimonial de sagração, a obediência ao imperador exerce uma função imperativa dentro de uma ordem constitucional, isto é, condição legal e limitadora dos poderes. Esta formulação, presente no juramento ao imperador, contrasta com o juramento de sujeição prestado a D. João VI, no cerimonial de sua aclamação, em 1818. Neste, os súditos ocupavam um papel desprovido de poder e decisão, em que a obediência é uma obrigação. No caso da sagração de D. Pedro, trata-se de restringir o poder que cabe a cada um, pelo respeito a condições normativas (deveres e lei estabelecidos conforme o "direito natural e das gentes"). E cabe também ao imperador o papel de velar pela observância da lei de uma legislação, cuja legalidade estava fundamentada nestes princípios jusnaturalistas. Em vários elementos do cerimonial indica-se que a origem do poder político é anterior e superior ao seu exercício por qualquer poder institucional: a vontade divina e a do povo. Concebe-se o poder político como ilimitado, mas não propriamente do poder do imperador porque este se insere agora numa distribuição constitucional dos poderes. E aquele poder ilimitado e esta distribuição exigem uma obediência à lei e à Constituição, que se admite como sendo garantida pelo imperador, feito instrumento daquelas vontades. O ponto importante é justamente esta função instrumental do poder imperial. Em função dele, o imperador adquire uma função principal na monarquia constitucional: garantia de existência do regime monárquico porque fiador e mantenedor da legalidade constitucional. Além disso, o cerimonial da sagração vincula a razão natural com a obediência absoluta. A monarquia constitucional seria um regime que reteria estes elementos numa Assembléia Legislativa e num monarca.

O que procuramos ressaltar é que se trata agora de uma obediência política apenas exercida pelo conhecimento dos deveres, não mais por uma exigência alheia à razão dos homens. Mudou, portanto, a natureza do cerimonial político, mesmo ao fazer uso de procedimentos religiosos. Com a coroação de D. Pedro I, fez-se um uso moderno do procedimento antigo da sagração, o que acabou por produzir uma sujeição política fundamentada na razão universal do Homem. O poder político atribuído a D. Pedro I exerce-se em termos de um poder de império, entendido como um poder superior e vigilante; um poder que se legitima na Constituição porque é a expressão da vontade racional e soberana da nação, mas também no respeito que lhe impõe o trono. Tais são os fundamentos desta monarquia constitucional brasileira. 
Tudo isso nos permite concluir que a monarquia brasileira se apresenta associada à idéia de um império da lei, na primeira década de 1820; isto é, uma idéia de império que teria contribuído para fundamentar o título do novo Estado independente do Brasil, no qual o poder político governante é um poder superior e vigilante. Um poder de império que se manifesta na dimensão legal como expressão de uma vontade soberana e racional. A idéia de império supõe, assim, um Estado de direito, em que há direito porque a ordem legal se fundamentaria numa vontade superior (tanto divina quanto popular). E o exercício deste poder desdobra-se como um poder legal e constitucional, que ao mesmo tempo vela pelo respeito da ordem legal e se expressa na Constituição. A sagração é o momento em que o poder temporal de império é concedido a D. Pedro e quando também se caracteriza sua origem naquela vontade superior. 